\title{
Attempting to Secure a University Education while in Prison Petey
}

\section{INTRODUCTION}

"At least I'll get a free education when I go to prison", I thought. I was so very wrong. On my own dime and in three different prisons and penitentiaries - youth, adult provincial, and adult federal - it took me four years to complete 80 percent of the credits required for one academic year of university education in Canada. At that rate, I would need twenty years to complete a four-year Bachelor of Arts.

I received a ten-year youth sentence. While I will refrain from providing details unrelated to the topic of education, I would like to say that if I could turn back time and not commit my crime, I would. Because I cannot do that, I focus on my present so that I can create a positive future for myself and my loved ones. Despite our crimes, all prisoners deserve an education.

Given that my foreseeable future would be spent behind bars after receiving a ten-year youth sentence, I set my sights on obtaining an education so that I could have a future upon my release. A university degree would assist me with supporting my younger brother - six years old at the time of my arrest - when we could have contact again. My brother, now nineteen, lives with me and I am one year away from graduating from law school. By dedicating my career to social justice, law and fighting for marginalized peoples' rights, I am going to take this system down. In this critical reflection, I describe my educational experiences across three different levels of incarceration in Canada - juvenile detention, adult provincial, and adult federal.

\section{JUVENILE DETENTION}

The easiest type of government-approved education I completed while incarcerated was high school. I was in a juvenile detention centre that held anywhere between 60 to 120 youth prisoners and they had a school built into the prison. Within the school complex, there was a gym, a weight room, a cafeteria where we could also cook, a library, several classrooms and offices for the school administration. Classes were co-ed and typically had fewer than five prisoner-students, boys and girls between the ages of 12 to 19 . We had supervised Internet and computer access during regular school hours. 
The best room in the school was the cafeteria, which is where I met Lyn, my Prime Teacher, who was also the nutrition and sewing teacher. Lyn looked like the grandmother you wish you had, to whom you could tell anything, anything, and it would not surprise her. Lyn had seen it all and worked with all types of difficult children. She treated each student the way they treated her, rather than a prejudgment based on their crime. This made her classroom the only one that felt normal in.

I completed high school while in juvie (juvenile detention) and volunteered as a teacher's assistant (TA) in the cafeteria and sewing room. I often cooked with teenagers who had severe mental impairments, which was extremely rewarding and simultaneously heart crushing. One boy, Aaron, was an eighteen-year-old with the mental age of a five-year-old. He could do anything, even bake rainbows into his cookies, if he worked with me, only to be restrained and thrown into segregation a few hours later for acting like a five-year-old that had a tantrum because he did not want to go to his room.

As the only graduating student, there was no graduation ceremony with the cap and gown for me. I received a round of applause at the end of the year education assembly, which was far from the prom and "best years of our lives" speech and ceremony I anticipated as a little girl. On a positive note, I received a $\$ 1,000$ scholarship for academic merit and for writing a compelling essay. I did not know it at the time, but that would be the only external funding I would receive for my education during my entire imprisonment.

I was the first to begin university in the youth prison. I started a double major Bachelor of Arts degree in French Studies and Psychology from Athabasca University, while volunteering as a TA. Each course was approximately $\$ 700$ and I would have to take ten courses a year for four years to earn the degree. I had a couple of thousand in savings from a summer job that I was going to use to begin my courses. I began with statistics. I was permitted supervised Internet access to complete my coursework during class hours, and to interact with the other high school students in a socializing and mentoring capacity. To everyone's dismay and after exhausting all appeals I knew of at the time, I was transferred to Vanier Centre for Women (adult provincial facility) after one month into my first Athabasca course, because I had turned twenty. I was assured that because I aged out of the youth system and my sentence was not converted to an adult sentence, my access to education would be the same or greater in the adult provincial system than it was while in juvie. 
My final assessment is that I could complete a university degree in the youth system, provided that I had the money necessary to pay for each course individually. However, being motivated to stay on track became increasingly difficult over time because I was not bound by the high school deadlines and was prone to depression - not to mention the structural difficulties I experienced when trying to take university courses.

\section{ADULT PROVINCIAL: VANIER CENTRE FOR WOMEN}

Vanier Centre for Women offered a very different educational experience. Like my experience in the youth system, I was also the first woman to work on a university course while in Vanier. I was not permitted access to a computer and there was most certainly no access to the Internet; I was provided with a tiny pencil (about the length of a thumb), a six-inch floppy ruler, and a scientific calculator only after I appealed to the Ombudperson's office and the Office of the Advocate for Children and Youth, who intervened on my behalf. I would sharpen my tiny pencil on the cement in the cells because a real pencil sharpener was considered a contraband weapon.

The cell searches were the most discouraging and happened two to three times per week. I was double bunked in a cell designed for one and had my mattress on the floor, beside the toilet. My cellmate, May, was deaf, and I used to pretend not to hear her loud farts, which helped her relax a little bit when we were stuck in our cell for days on end under lockdown. I found it hard enough to be in Vanier with my hearing and cannot even begin to imagine the difficulties May experienced in this forgotten hellhole.

Course material was simply a stack of loose paper because that was the only form of education material allowed - I was not permitted staples, binders, duo-tangs or folders, audio tapes, videos, CDs, or DVDs. Yet, prison guards felt the need to repeatedly throw my course material across the cell, which had the same effect as shaking out a book with no spine so the pages would fly around in a beautiful mess.

Athabasca courses include remote access to tutors and professors. However, I could not take advantage of these because the tutors do not accept collect calls. I was completely on my own in terms of learning the material and could not turn to anyone for help because most of the women I met in Vanier never completed high school. I did not see prisoners completing 
their high school education, or any education, while at Vanier, nor were they provided with any opportunities to do so.

There were numerous prison practices that were out of my control that created delays in my educational progress; these delays were so excessive that my course expired before I could complete it. These delays were purely the fault of the prison and the government ministries responsible for my transfer. For example, I had to submit my assignments using snail mail, because I was not permitted to scan and e-mail them. My address change was not communicated with Athabasca despite the fact that I was informed that it was, which caused my evaluated work to be mailed to the wrong prison. Mailing larger documents out of the prison and receiving evaluated assignments in return was an administrative hassle, adding months to what should have required days. I was livid enough that I successfully convinced the Ministry of Children and Youth Services to pay for two extensions so that I could complete my exam. My probation officer assured me that I would be able to continue my courses in a similar capacity as in the youth prison. This was a blatant lie and completely at odds with what the youth system ought to stand for. My probation officer knew to expect another call from the Ombudperson's office if this was not resolved quickly, and therefore processed funding for the extensions. An adult had to supervise my exam, but for some bizarre reason, no one could be approved to do so. Eventually, a Child and Youth Worker (youth prison guard) came from the juvenile detention centre to visit with me so that I could write the exam.

Near the end of four grueling and unnecessary months in Vanier, I was double bunked with a violent and horrendously gassy 50 -year-old woman named Heather. Heather struggled with lifelong mental illness, and while she was extremely caring, she was also easily angered and unpredictable. Again, I slept on the mattress on the floor by the toilet, which was significantly worse in this cell. Sometimes the guards would open our door hatch out of pity because of the smell; it is normally used for meal trays and to handcuff prisoners before the cell door is opened.

My final assessment is that I could not complete a degree in Vanier. I struggled and fought the prison administration for four months to finish one course that did not require me to conduct external research. The lack of access to research tools and tutors, combined with the frequent and destructive cell searches is enough to turn most students off of learning, even if they did magically acquire the money to fund their courses. Yet, 
we are told that improving ourselves through education is one of our best chances of successfully reintegrating post-incarceration.

\section{ADULT FEDERAL: GRAND VALLEY INSTITUTION FOR WOMEN}

I was transferred to Grand Valley Institution for Women (GVI) two weeks after the Ashley Smith murder, because I still had several years left of my sentence. Administratively, the person who authorized my initial transfer to the adult system could only authorize a transfer to the provincial system. The onus was on me, a youth, to request a hearing in front of a judge for a transfer to the federal system, where conditions are expected to be better. The Youth Criminal Justice Act (2003) had recently been overhauled and I was like a live action kink they were trying to work out.

Upon arrival at GVI, I was illegally placed in maximum-security for five months, which resulted in a small now-settled lawsuit, but which also held back my educational progress. I had no access to a computer or Internet, but could use pens, along with other common writing and learning tools. I spent more time, however, challenging my security classification and conditions of confinement than working on my course. I felt very alone in GVI, became anaemic from the lack of adequately nutritious food, and let myself wallow and lose focus during those first months.

Like all federal prisons in Canada, GVI is only required to provide prisoners with up to a grade 12 level of education. Prisoners who have not graduated from high school are enrolled in school as their prison employment, though the actual school was too small and bare to resemble anything of the sort. Post-secondary education, on the other hand, is not a component of prison-mandated programming and is thus not approved as a prison job. I was expected to work during business hours and study on my own time. My daytime prison job was being the janitor in the maximumsecurity wing and then I spent my evenings doing coursework.

When I was finally released from maximum-security and housed in the general population, I was hired to work as a tutor at the elementary school level. This is where I met Heather again. She was enrolled as a student in the elementary class, because her mental illness prevented her from studying at a higher level. It was my job to teach Heather fractions. Heather tried and tried, but could not understand how to do fractions or why she would 
ever need them. Instead of reacting in anger, as was common with Heather, she sat still and cried silently. After seeing this woman behave violently towards other prisoners, I was reduced to tears and ended up quitting that job because Heather was so broken by the fact that she could not understand fractions. I, on the other hand, was broken by the knowledge that Heather was eternally doomed to have her "prison job" as a student in an elementary class from which she would and could never graduate.

Prison jobs are modern slave labour and "wages" have not been updated since the 1980 's, so they are negligently and criminally out of date. At my highest, I earned $\$ 6.90$ per weekday of work, minus several deduction fees, such as $\$ 20 /$ month for cable, even if there is no 13-inch TV in one's cell. Women used their earnings to purchase stamps and envelopes to contact family, food to supplement the inadequate amount provided, and sanitary pads and tampons to supplement the limited and insufficient quantities we received. Anything left over usually went to phone calls with children and family at $\$ 0.12 /$ minute for local calls, and significantly more for long distance. With five regional federal prisons for women in Canada, the overwhelming majority of phone calls are long distance. I did not have money left over to enroll in university courses.

The teacher in charge of the high school department was an angel in disguise who I will call "the Rock". He explained early on that he was only mandated to work with the high school students and to facilitate high school courses. In spite of this, he helped me sign up for university courses and let me call tutors from his office as long as I was discreet. The Rock only helped me because he wanted to, risking being reprimanded if other prison authorities caught him helping me with my university courses.

I completed a few French and Spanish courses while in GVI, which presented their own challenges. I could access a CD player, which enabled me to speak along with the instructor to improve my pronunciation. The Spanish course also required that I access more antiquated technology, such as a VHS player in order to follow a specially designed soap opera. Thankfully, the prison did have a television/VCR trolley, reminiscent of my childhood education. After enough complaining, I was able to book the TV to use during a specific time in one of the rooms that prisoners could use for meetings with a volunteer. It was basically a small room with a couch where guards could look in, so it was not considered a security risk to let me watch a few episodes of Destinos. I learned more Spanish from our House Cook, 
Keyla, who was stopped at the Canadian border with drugs. I learned very quickly that, if another woman is driving me crazy, Ella stressa mi cabeza!

My French and Spanish exams had an oral component. I could not call the professors collect to complete the exam and the Rock could not set aside that much time on his office phone. I was given use of the telephone meant for prisoners' first 15-minute phone call when they arrive at GVI. At the end of a long hallway, there was a set of heavy metal double doors that loudly buzzed open with an alarm sound and clanged shut every few minutes. Those doors separated the visiting area from the general population of the prison. Within arm's length of this door was a small, bulletproof window. The window had a hole, through which the guards passed the phone receiver attached to a fairly short, curly phone cord. I had a chair, and balanced my French notes on my knee as I struggled to hear the professor through the buzzing and slamming doors, and the regular activity in the hallway. I am amazed that the professor could hear me at all. It was awful.

One time, after ample complaining, I succeeded in using one of the boardrooms that are normally reserved for meetings with parole officers to write a Spanish exam. I had a table, a fancy chair on wheels and no background noise. It was wonderful.

My final assessment of my experience in GVI was that, theoretically, I could complete certain courses, but a full degree would be unlikely. There is simply not enough access to research tools, and nothing in the way of motivation or financial resources. It is simply too hard to keep going for the length of time it would require to complete a degree. I would have run out of money fairly quickly had I not encountered the obstacles that delayed my education while in prison: time delays due to snail mail and having to work a different job in the prison during business hours; telephone communication difficulties; the lack of a tutor to assist me with scheduling and understanding the material; and demotivation due to my confinement and the slow progress I was making in school. Any successes that I had were after blatant opposition from, and fully despite, the prison system.

I will end with a warm and happy memory about education and prison, courtesy of the Rock. Because more prisoners graduated from high school while in GVI than they did in juvie, I was able to attend a small graduation ceremony in the GVI gymnasium. Five women graduated. They had the caps, robes, flowers and their diplomas. They each walked up, collected their diploma and flowers, had a standing ovation, and had a graduation 
photo taken. The Rock knew I did not have a ceremony while in juvie, so after the official graduations, when everyone was mingling, the Rock had me borrow a woman's gown and hat, flowers, and diploma (her name was not visible) to pose for a photo. One of the guards thought I was stealing the gown and was coming over to throw me in the hole before the Rock explained why this was a good thing. Not only did I avoid the hole while breaking prison rules in an unorthodox manner, I finally felt like I graduated.

\section{ABOUT THE AUTHOR}

Petey is a young woman with a passion for human rights. She is currently in law school, using her experience within the correctional system to advocate for herself and others, and is dedicating her legal career to Criminal Defence, Indigenous law, and Charter law. Petey is a distinctive example of a person who has seen the inside and survived to flourish on the outside. She is using her second chance to improve her community and country. You can contact her at petey@live.ca. 